\title{
Migration ethics in Genesis 47:1-12 as a limelight for Nigerian migrants
}

\begin{tabular}{|c|c|}
\hline \multicolumn{2}{|c|}{$\begin{array}{l}\text { Authors: } \\
\text { Favour C. Uroko } \\
\text { Mary J. Obiorah } \\
\text { Success Nnadi, }\end{array}$} \\
\hline \multicolumn{2}{|c|}{$\begin{array}{l}\text { Affiliations: } \\
\text { }{ }^{1} \text { Department of Religion and } \\
\text { Cultural Studies, Faculty of } \\
\text { the Social Sciences, } \\
\text { University of Nigeria, Nsukka, } \\
\text { Nigeria }\end{array}$} \\
\hline \multicolumn{2}{|c|}{$\begin{array}{l}\text { 2Department of Mass } \\
\text { Communication, Faculty of } \\
\text { Arts, Institute of } \\
\text { Management and } \\
\text { Technology, Enugu, Nigeria }\end{array}$} \\
\hline \multicolumn{2}{|c|}{$\begin{array}{l}{ }^{3} \text { Department of Old } \\
\text { Testament and Hebrew } \\
\text { Scriptures, Faculty of } \\
\text { Theology and Religion, } \\
\text { University of Pretoria, } \\
\text { Pretoria, South Africa }\end{array}$} \\
\hline \multicolumn{2}{|c|}{$\begin{array}{l}\text { Corresponding author: } \\
\text { Success Nnadi, } \\
\text { successnnadianene@gmail. } \\
\text { com }\end{array}$} \\
\hline \multicolumn{2}{|c|}{$\begin{array}{l}\text { Received: } 17 \text { Nov. } 2020 \\
\text { Accepted: } 05 \text { July } 2021\end{array}$} \\
\hline \multicolumn{2}{|c|}{$\begin{array}{l}\text { How to cite this article: } \\
\text { Uroko, F.C., Obiorah, M.J. \& } \\
\text { Nnadi, S., 2021, 'Migration } \\
\text { ethics in Genesis 47:1-12 as } \\
\text { a limelight for Nigerian } \\
\text { migrants', Verbum et Ecclesia } \\
\text { 42(1), a2188. https://doi. } \\
\text { org/10.4102/ve.v42i1.2188 }\end{array}$} \\
\hline \multicolumn{2}{|c|}{$\begin{array}{l}\text { Copyright: } \\
\text { (c) 2021. The Authors. } \\
\text { Licensee: AOSIS. This } \\
\text { is licensed under the } \\
\text { Creative Commons } \\
\text { Attribution License. }\end{array}$} \\
\hline \multicolumn{2}{|l|}{ Read online: } \\
\hline 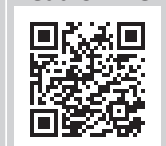 & $\begin{array}{l}\text { Scan this QR } \\
\text { code with your } \\
\text { smart phone or } \\
\text { mobile device } \\
\text { to read online. }\end{array}$ \\
\hline
\end{tabular}

In Genesis 47, Jacob and his descendants were regularly migrants in Egypt. This article examines this text and its interest in the contemporary migrant crises affecting Nigerians. Findings reveal that Genesis 47 encourages regular migration and discourages irregular migration. The migration ethics in the pericope is contrary to the contemporary migration model adopted by Nigerians. This article concluded that the migrant crises affecting Nigerians occur as a result of the high level of irregular migration ethics adopted by Nigerian migrants. To find a solution to the problem, there should be the provision of adequate enlightenment and information to promote regular migration amongst Nigerians. Nigerian migrants should endeavour to present themselves to the authorities of their destination countries. This research employs the exegetical and phenomenological methods.

Intra/interdisciplinary implications: This research is based on the misunderstood migration ethics in Genesis 47. Contrary to what is obtainable amongst Nigerian migrants, Genesis 47 encourages regular migration. Nigerians, just like Jacob and his descendants, migrated to other countries mainly for economic survival. However, it was discovered that most of the Nigerian migrants are irregular migrants. Disciplines implicated include Old Testament, Cultural Studies, and Sociology.

Keywords: Genesis 47; environmental change; migration ethics; Jacob; Egypt.

\section{Introduction}

Migration is the most effective way to reduce poverty and share prosperity. Inter-regional and international migration is on the rise. In order to effectively understand and appreciate the significance of probing into the migration dynamics, the narrative about Joseph in Genesis 47:112 is paramount. In Genesis 47:1-12, ethics is fundamentally theological because ethical issues are at every point related to God - to his character, his will, his actions and his purpose (Adigwe \& Arubalueze 2004). Thus, most of the research on Genesis 47 has explored the theological angle of ethics, that is, how the Genesis narrative presentation of God impacts its ethical teaching. Thus, theology and ethics are inseparable throughout Genesis 47:1-12 narrative. The ethical perspective in the pericope reveals care for Jacob and his household who were migrants in Egypt. It was an economic crisis that forced Jacob to seek the means of survival for himself and his household. The economic crisis caused by severe drought leading to famine could have brought about the termination of Jacob's lineage. Genesis 47 presented Joseph coming to Jacob's aid, and his devising of a plan to save his kinsmen - indeed, the whole non-Israelite world - by giving them protection and provision in the world's most prosperous environment (Philpot 2018:694). The type of migration undertaken by Jacob and his family in Genesis 47:1-12 was through legal routes with proper bureaucratic measures. The Pharaoh having benefited from the services of Joseph gave the land of Goshen for the habitation of the Egyptian immigrants.

Existing literature has not adequately explored the theological response to the contemporary migration crisis of Nigerians. Genesis 47:1-12 has similarities with the crisis that Nigerian migrants are going through. The analysis provides insight into the insecurity, threats, killings, destruction of properties, and anxiety and the mistrust Nigerian immigrants go through. Genesis 47:1-12 is believed to speak anew to the contemporary migrant crisis affecting Nigerians in Africa, Europe and other nations of the world. This research employs the exegetical and phenomenological methods.

\section{Understanding Genesis 47}

Genesis is predominantly the book of Hebrew Origins. The historical context of the pericope reveals that there was a socio-economic problem. Genesis 45 sets the stage for the migration of 
Jacob and his family. It was here that Joseph reveals himself to his brothers and also asks them to bring Jacob, his father, to Egypt. The pericope is a discourage narrative that detail migration of people for survival. There was famine in Egypt. The peculiarity of the famine was that it extended over the neighbouring countries ( $\mathrm{Gn}$ 41:56) and that is the fact of significance in regard to the history of Israel, with which the narrative in consequence resumes contact (Moss 1930:495).

When Joseph's brothers came to Egypt, they were recognised by Joseph. But, the brothers did not recognise him. Little wonder, they were first of all subjected to intimidation by Joseph without their knowing it. Joseph accused his brothers of being spies, who had come to Egypt to invade the land. Furthermore, Joseph threatened to imprison Benjamin for stealing his silver cup of divination, but the brothers pleaded for mercy to reign over judgement (Gn 44:16-18). Judah pleaded that he be imprisoned instead. Judah and his brethren were waiting for an answer and could not but be amazed to discover, instead of the gravity of a judge, the natural affection of a father or brother (Blue 2021:1). Judah was pleading that Benjamin be released for his alleged crime of stealing the silver cup.

At this point, Joseph could not hold himself and drove his subordinates outside leaving his brothers with him. Joseph thereafter revealed himself to his brothers and asked them to go and bring their father Jacob to Egypt (Gn 45:3). Joseph told his brothers that he was Joseph. The effect of this announcement can be better imagined than described. Hitherto he had been known to his brothers as Zaphnathpaaneah. Now, he evidently speaks to them in Hebrew (Swaggart 2013:90). Joseph's appeal to the dumbfounded brothers to draw closer to him is a realistic touch to keep his brothers at ease (Clifford \& Murphy 2006:40). In Genesis 45:9, Joseph told his brothers to go and bring their father and the entire family to Egypt. This was possible because from Genesis 45:8, Joseph told them that he was in charge of Egypt and their survival. He also told them that they would live in Goshen where all their needs would be catered for. In Genesis 45:18, the Pharaoh gave instruction that Joseph's brothers are free to migrate to Egypt. In verse 25, Joseph's brothers returned to Canaan and told the father everything that about Joseph and his proposal of them migrating to Egypt. This was the message Joseph wanted his brothers to convey to their father. When Jacob eventually heard this, it was one of the greatest days of his life (Guzik 2018).

When Jacob and his family finally arrived Egypt, Joseph invited his father to have a discussion with the Pharaoh $(\mathrm{Gn}$ 47). Now he found his brothers repentant for their sins, mindful of himself (for Judah had mentioned him twice in his speech), respectful to their father, and very tender of their brother Benjamin. Now they were ripe for the comfort he designed them, by making himself known to them. The pharaoh gave orders that Joseph should fetch Jacob and his family down to Egypt, and Joseph's despatch of his brethren, accordingly, back to his father with those orders (vv. 16-24) and thereafter Jacob was brought to Egypt (Henry 2006:86).
Joseph's (and presumably God's) efforts:

Secure not only his family in Egypt but also the Pharaoh's absolute rule over the land and persons of all Egyptians (Gen 47: 13-26), with the exception of the priests. (Lee 2001:224)

In Genesis 46, Jacob is here moving to Egypt in his old age, forced thither by a famine and invited thither by a son. In verses 1-4, God sends Jacob thither, all his family goes with him (vv. 5-27) and Joseph bids him welcome (vv. 28-34) (Henry 2006:87).

The circumstances that Joseph made his brother's to go through was not a protracted scheme of revenge but a course of education, which contained a brief version of the process by which he himself learnt that his gifts - good looks, authority, the remarkable abilities to interpret dreams and deliver the land from a seven-year famine - were all gifts from God to save life (Lee 2001:225).

\section{Close reading of Genesis 47:1-12 Joseph and regular migration}

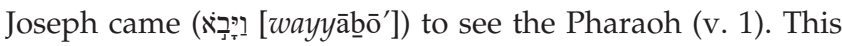
was in respect to the arrival of the Jacob and his family from

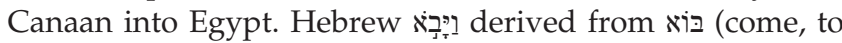
come in, to go in $\left.\left[\underline{b} \bar{o}^{\prime}\right]\right)$ was used to mention the mission of Joseph's presence in the palace to seek the Pharaoh's permission. Part of this permission was that Joseph did not want his family to be settled amongst the Egyptians but near himself and the Pharaoh in the delta-land of Goshen, the best part of the country (Vawter 1956:286). Still, in verse 1, Joseph

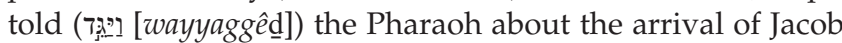

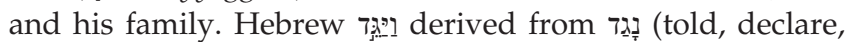
fully reported [nagad]) in the context means that Joseph told the Pharaoh about the arrival of Jacob and his family. It is Joseph's modest approach in informing the Pharaoh about the new migrants. Literally, nagad demonstrates that Joseph had to take a step in making known to the Pharaoh the arrival of his family members. In the last phrase of verse 1, Joseph told the Pharaoh where Jacob and his family are based.

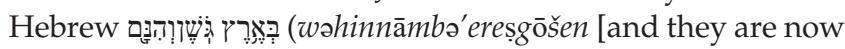
in the land of Gosen]) indicates that Joseph had the idea of where the migrants were and also would like the Pharaoh to have an idea of where Jacob and his family were waiting.

In verse 2, Joseph took (לקֶ) the migrants to the Pharaoh. Hebrew לִ לִ (lāqah) means he took, he selected, he sent and also he captured. Thus, it shows that Joseph selected some of the migrants and took them to the Pharaoh. In the second sentence, it was confirmed that he selected five of these migrants. Thus, Joseph presented these five migrants to the

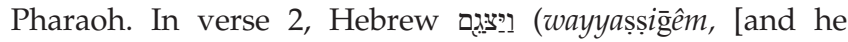

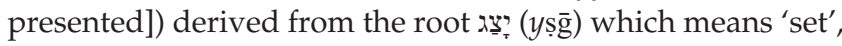
'made' or 'established' was used to relate that the migrants were set in the presence of the Pharaoh. Hebrew wayyașșigêm could also mean that Joseph announced the arrival of the migrants to the Pharaoh. His announcement of their presence began with his introducing them, so that they might have a discussion with the Pharaoh and Pharaoh may have the opportunity of accurately profiling them. 
The Pharaoh became the subject of the discourse in verse 3. In verse 3, the Hebrew phrase רֶֶ: (wayyō'mer [he said]) was used to introduce the Pharaoh's interaction with the Hebrew migrants. Hebrew רֶּ (wayyō'mer) from the root rma [say] is a description of the prologue of the questions of the Pharaoh to the migrants. After rma, the question becomes 'what is

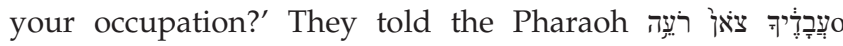
(ró'êhșon' $\breve{a} \underline{b} \bar{a} \underline{d} e \underline{k} \bar{a}$, [Your servants are shepherds of sheep]) affirming what Joseph had told them in Genesis 46:34.

In verse 4, after responding to the Pharaoh, concerning their mission, they told the Pharaoh that they wanted to stay in Egypt to continue their trade. The Hebrew phrase (lā $\bar{u} \bar{u} b \bar{a}^{\prime} \bar{a} r e s$, to sojourn in the land) signifies an honest response to the question of the Pharaoh. This shows that Jacob and his descendants were very much in need of being granted migrant status in Egypt. They explained to the Pharaoh that they wanted temporary residence only, as sojourners (גרים), without the full rights of landowners, until the famine was over. It is only then that they put forward their request (we pray you, let your servants dwell in the

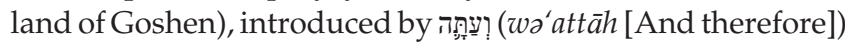
that they are allowed to settle in Goshen (Scullion 1991:169).

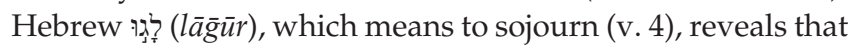
the sojourning is just for a time until the famine goes down. The sojourn was not intended to be forever. The use of sojourn also shows that Jacob and his family reckoned themselves as migrants, for it also means to reside. The sojourner in most of the places it was used in the Old Testament resides in the destination country on a temporary basis with limitations to rights and opportunities. Also, lāg $\bar{u} r$ was used to specifically show that 'ereș [a land] is paramount and that the sojourner was welcomed. This is the reason why in verse $4, b \bar{a}^{\prime} \bar{a} r e s$ was added to $l \bar{a} \bar{g} \bar{u} r$ [to sojourn] indicating the need for a land to be granted as a sanctuary for Jacob and his family. This 'eres may also be a place of refuge for the sojourner (migrant).

Furthermore, in verse 4, they further modified their sojourning intent with the maxim 'the famine is severe'

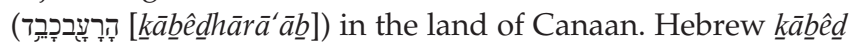
literally means heavy, hard, oppressive and even a great famine. It is because of this famine that there was no pasture

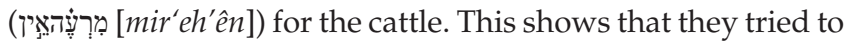
make the Pharaoh understand that their movement was necessary owing to the fact that they valued their cattle lives.

\section{Jacob and his family sojourning in Egypt}

ThePharaoh has not yet responded to Joseph's communication in verse 1 . He now takes it up, but with a conscious nuance 'êlek $\bar{a} b \bar{a}^{\prime} \bar{u} w \jmath^{\prime} a h e \underline{k} \bar{a}^{\prime} \bar{a} \underline{b} \hat{k} \underline{k} \bar{a}$ [Your father and your brothers to you they come]). In verse 5, the Pharaoh showed knowledge of the profiling of the migrants who were seeking for refuge in his country. He told Joseph: wa'ahek $\bar{a}^{\prime} \bar{a} \underline{b} \hat{k} \underline{k} \bar{a}$ [your father and your brothers], indicating that he had confirmed them as regular migrants with the correct profiling. This indicates that apart from the Pharaoh knowing Joseph's father, he also recognises that other members of Joseph's family, not specifically Joseph's immediate family, had come to Egypt. Furthermore, apart from using the second personal pronoun (your) on Joseph's brothers, the Pharaoh furthermore said that they were at the mercy of Jacob. Hebrew 'êlek $\bar{a}$ [to you] (v. 5) was used to show the person that Joseph's father and brothers came to. It indicated that in Joseph's hands lies the safety of these new Egyptian immigrants or sojourners your father and your brothers have come to you. Hebrew 'êlek $\bar{a}$ was also used to show the Pharaoh's acceptance of all the profiling process and also to show his gratitude to Joseph for being a blessing to him and the Egyptian people. Had it been that Joseph had not contributed evenly to the growth of the Egyptian nation, the Pharaoh would have used 'ellay [to me, to Pharaoh] which would have made the migrating into Egypt of Jacob and his family very difficult. Hebrew 'ëlay would have shown that Joseph's authority in Egypt was limited. In verse 6 , the second phrase, the Pharaoh told

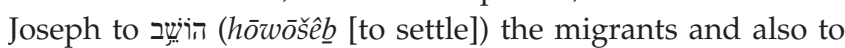
look חיל אנשי anshey chayil; stout or robust men were capable of bearing fatigue and of rendering their authority respectably (Clarke 1832). The use of hōwōšê in the context shows that Joseph had been given the powers to allow the migrants to settle themselves, to live in Egypt and to stay in Egypt. הiוֹשي is derived from the verb activity that must be in a place. In the case of Jacob and his family, Joseph would allow them to sit in a land. Sitting is for comfort; it is a way of inhabiting a place. The place of settling

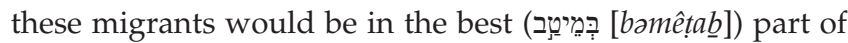
the Land. Hebrew bamettab could also mean in the best portion, and it is mostly used for field and vineyard. This could also be seen in Genesis 47:11 and Exodus 22:5. Hebrew

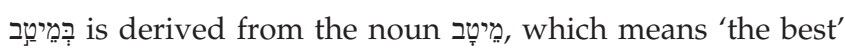
portion. In the context of its usage, bəmêta $\underline{b}$ means any fertile land that will be good for grazing owing to the request of Joseph's brothers in verse 4 . In fact, the Pharaoh suggested that Goshen is the best part.

Thus, the Pharaoh looked for people amongst the immigrants who were competent physically and also intellectually to make them leaders in his cattle farm. The condition was to ensure that the skill that the migrants claim to have needs to be proven by the Pharaoh himself. Being שִ [śârê] placed these migrants as supervisors of other shepherds of the Pharaoh.

\section{Jacob's appreciation of his status as an Egyptian immigrant}

This section begins with the introduction of Jacob which was

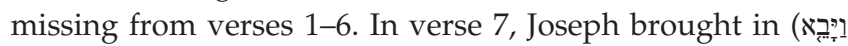
[wayyābêe]) Jacob before the Pharaoh. Here, the Hebrew word wayya âbê derived from the verb means to bring, go in, or to advance something. Jacob advanced from his audience participation since verse 1 to a participant. After bringing in Jacob, whom he did not present

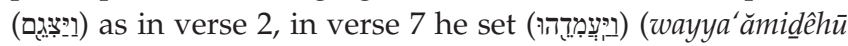
[and he set him]) Jacob before the Pharaoh. In verse 2, the brothers were just made to face the Pharaoh, so that he could 
recognise them, but in verse 7 , Jacob's examination was beyond presentation, but he was set. Hebrew wayya'ămidêh $\bar{u}$

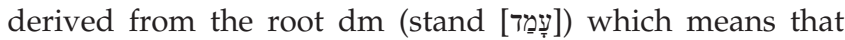
Jacob was caused to stand, which was in submission to the person sitting down (the Pharaoh). It also means Jacob was stationed and made to stand firm before the Pharaoh to introduce the migrants he led to Egypt.

After the opening greetings from Jacob, the Pharaoh started the discussion. In verse 8 , the Pharaoh asked Jacob about his age. The Pharaoh said (kammāhyəmêšnnê hayyek [what are the days of the years of your life]) which was a way of showing his recognition of Jacob's countenance. Jacob may have looked like someone who had sad experiences. However, Pharaoh needed to hear from Jacob's mouth in order to validate his claims. According to Henry, 'what days are the years of your life' was a question usually put to old men because of the fact that it is unnatural to despise it (Henry 2006:88). Instead of saying kammāhšznê hayyek $\bar{a}$ [what are the years of your life] to show that he only needed the age of Jacob; he instead added yəmê [days] and thus asked kammāhyəmêšznê hayyek $\bar{a}$ [what are the days of the years of your life] imploring Jacob to explain how he had lived his days. Jacob was intelligent enough to understand this question.

In verse 9, first, Jacob referred to the days of his years as a

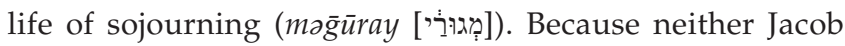
nor his fathers had actually possessed the land of Canaan, describing life as a sojourning was a fitting evaluation to give (Study 2020). Hebrew maḡūray means a stopover place, place of residence for the alien, a dwelling place and a place of lodging. Jacob informed the Pharaoh that his life has been that of a temporary resident (maḡüray) who had been living the life of a stranger in all the lands he had been to. In verse 10, after the explanation of Jacob, his years and how terrible they had been, he felt that it was time to go, with nothing to say anymore. At least, he had been able to convince the Pharaoh that he was in dire need of a

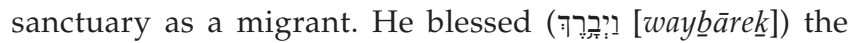
Pharaoh as a mark of exit from the presence of the Pharaoh. It could be recalled that in verse 7 , ברב the welcome greeting, whilst in verse 10 , it was a departure greeting.

\section{The care for Jacob and his entire household as immigrants in Egypt (vv. 11-12)}

The discussion shifted from the Pharaoh and Jacob to Joseph

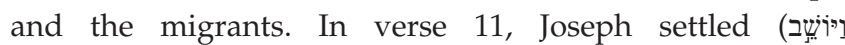
[wayyōwōšêb]) Jacob and his family in the best land which

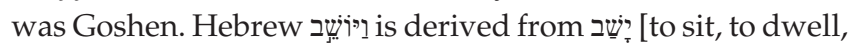
to remain] showing that Jacob and other migrants remained in Egypt, showing that Egypt settled them. It made the remaining years of Jacob to be joyful and fulfilled (eds. Desmond \& Baker 2003:466). They became occupants of a land in Egypt.
The provision of possession which turned out to be the best was on what the Pharaoh had commanded (șiwwāh]).

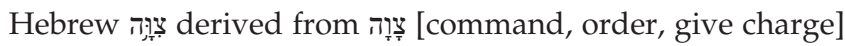
signalled the fact that Pharaoh's instruction to Joseph was a command that must be obeyed. It was not an option. It is a commission and instruction that he gave to Joseph, which involve the protection, provision and care for the migrants (Kept 2014). These verses follow, at least in part, on 46:28 47:6 of Genesis. In the last part of verse 12, Hebrew לֶ. (lehem [bread, food]) was used to indicate the provisions made to Jacob and his family by Joseph based on the command of the Pharaoh.

The exegesis has been able to show how Jacob and his family found their way into Egypt. It indicated how Joseph ensured that the migrants passed through the border policies of Egypt. Notwithstanding the fact that he had Egypt at his disposal to aid the irregular migration of these migrants into Egypt, Joseph made them to pass through Egypt's border policy. It also redefined how the migrants made case for the Pharaoh to look into their plight and grant them a sanctuary in Egypt.

\section{Why and how Nigerians migrate}

Some Nigerian migrants engage in regular migration whilst others engage in irregular migration. Nigerians migrate voluntarily, fleeing perceived or realistic man-made threats. Obiorah attributes this to the dynamic nature of human beings which makes them search for survival and improvement in their state of living (Obiorah 2019:127). In the search for survival, different strategies are used by Nigerian migrants. These strategies include regular and irregular migration. The cost of emigration from Nigeria forced many Nigerians to seek alternate routes. Most Nigerian migrants take the risk of crossing the Mediterranean Sea and borders. Sometimes, these Nigerian migrants end up as asylum seekers. Dockery revealed that Nigerians make up the fourth-largest group of asylum seekers in Europe (Dockery 2018:1). Tens of thousands risk the perilous journey across the Mediterranean every year. Nigerian migrants know the enormous risks involved in crossing the Mediterranean Sea, but they decided to migrate with the hope that they will live a better life outside the shores of Nigeria.

A larger percentage of Nigerian migrants consist of young people. Every year, thousands of young people graduate from tertiary institutions and are pushed into a job market that does not have any room for them. With limited resources and competent skills to create their own jobs, they end up competing for the few available vacancies. In a desperate attempt to make a living, many people willingly do anything legal and illegal. One of the things they do is leave their loved ones behind and travel across seas to foreign lands where they often become migrants (Abara 2019:1). Nigerian migrants - whether they are regular or irregular migrants have certain deficiencies in their opportunities and prospects in the receiving countries. Several measures were put in place by the United Nations and the International Labour 
Organization to militate against these deficiencies. International Convention on the Protection of the Rights of All Migrants and Members of their Families was drafted by the UN and ILO to protect migrants. The Convention entitles migrant workers and their families to adequate protection by the government and that they should be treated with human dignity whether they are regular or irregular migrants. They ought to be given a fair hearing at all times. They have the right to join trade unions, access justice, get free education and observe their religion and culture. Migrant workers and their families merit to be treated as human beings, allowed free human associations, form trade unions, seek redress in a court of law or other tribunals, get medical attention when ill, send their children to school, relate with their countries of birth and retain their language. They also have the right to send money back home without extraneous taxations and protocols (Ozuru \& Okereke 2019:94). This convention could not stop the suffering that Nigerian migrants go through. Nigerian migrants do not enjoy certain social, economic and political rights. Edidong recalled that on 30 July 2020, a Nigerian woman who lived in Castel Volturo, Italy, had all her childbirth there. She was denied maternity grants and family benefits on the grounds that she was an immigrant and was supposed to have applied for aid through the proper procedures (Edidong, pers. comm., 04 September 2020). They also mock and harass illegal Nigerian migrants especially.

Some Nigerians engaged in smuggling some Nigerian migrants through risky routes and means. This has affected the reputation of Nigeria and Nigerian migrants as well. Nigeria has the reputation as a source for human smuggling which has caused (been causing) embarrassment for Nigeria. These embarrassments are seen when Nigerian migrants are being trafficked to other countries, including those far less developed than Nigeria. For instance, on 17 July 2020, Niger republic deported 42 Nigerians, citing irregular migration as the reason for their deportation (Olaide 2020). Compared to Nigeria, Niger is ranked at the bottom of the Human Development Index, with low per capital income, and it is a least developed nation in sub-Saharan Africa. Unfortunately, Nigerian migrants are subjected to abuse, inhuman treatment, forced labour and even death in these places.

It is now a tradition to see Nigerian migrants being deported to Nigeria. Because of reasons ranging from illegal entry to engagement in fraudulent activities, the receiving countries have been forced to take draconian decisions against Nigerian migrants.

\section{Genesis $\mathbf{4 7}$ and Nigerian migrants}

Genesis 47 discourages regular migration. With regular migration, the migrants do not infringe on the laws of the giving, transiting and receiving countries. As seen in the exegetical analysis of verse 1, the migrants presented themselves for profiling before they were granted immigrant status. The implication of this to contemporary Nigerian migrant crises is that some Nigerians migrated to their destination countries irregularly. This phenomenon escalated owing to technological developments. Mrs Kate concurred that this trend of falsification of papers by Nigerian migrants is very prevalent today because of technological developments (Kate, pers. comm., 12 June 2020). This is seen in the way people use application software in computer to manipulate figures, documents and pictures to be issued visa after the interview. Thepericopeindicates that Joseph, notwithstanding his position in Egypt, did not allow his family members to migrate illegally into Egypt. This is a challenge to friends and relations of Nigerian migrants who do so many fraudulent activities to get their wards into the destination country. Mr Jude (pers. comm., 04 April 2020) acknowledges that relatives of intending Nigerian migrants falsify papers 'in order to help their family members to succeed (Jude 2020)'.

Genesis 47:1-12 further reveals that there are so many benefits of engaging in regular migration. In verse 6, the migrants were given better living condition in Egypt. The implication of this is that irregular migrants are bound to suffer social, political and economic abuse, whilst regular migrants may not face these challenges. This is an eye-opener to Nigerian migrants in transiting and receiving countries. Irregular Nigerian migrants cannot apply for jobs, get work permits and are officially not recognised as refugees in the destination countries. This limits their chances of getting a decent job in the destination country (Pulse 2018).

The quest for better living is a major push factor for migration. Genesis 47:4 made it clear that most migrants seek economic survival. In verse 4 , Jacob and his family told the Pharaoh: 'We have come to live here for a while because the famine is severe in Canaan and your servants' flocks have no pasture'. This is an indication of the fact that the migrants were honest and specific in telling the Pharaoh their reason for migrating into Egypt. Supporting this line of thought, Kate (pers. comm., 12 June 2020) reported that most Nigerians migrate to other countries because of the yearning for a brighter future. It is also a way of running away from the frustration in Nigeria and seeking for a better life outside Nigeria. Thus, economic survival is one of the motivating factors that prompt Nigerians to migrate to other countries.

The Pharaoh in Genesis 47:11 proves that the social and legal rights of regular migrants are non-negotiable. Based on the exegetical analysis of verse 11, the Pharaoh instructed that Jacob and his family be provided with accommodation and food. It was part of the best Egypt had to offer at that time. This is a challenge to destination countries. Nigerians are denied care and sympathy by their receiving countries According to the office of the United Nations High Commissioner for Human Rights, the basis for this denial is because of the poorly informed or misinformed Nigerians migrants, especially with regards to the conditions governing entry, work and residence, skills required, cultural issues of the receiving country (United Nations High Commissioner for Human Rights 2020). For instance, take the case of Nigerian migrant crises in Libya, where Nigerians were sold 
in slave markets. Some Nigerian migrants intended to use Libya as a route into Europe.

In Genesis 47:3, there is an emphasis on the need for migrants to have a skill. The Pharaoh questioned Jacob and his family: 'What is your occupation?' The implication is that migrants are supposed to have been empowered with formal or informal education before leaving for their destination countries. This is to ensure that they do not constitute a nuisance to the receiving country. Some Nigerian migrants have educational and business skills. Nigerian migrants are in the destination countries for studies, and others for economic empowerment. However, it is important to reveal that some Nigerian migrants have little or no skill to survive in the destination countries. Even though some Nigerian migrants may have the skills, they end up abandoning their skills to pursue quick money. Following this line of thought, Mrs Aisha lamented that 'notwithstanding how academically proficient some Nigerian migrants claim to be, it does not change their character' (Aisha, pers. comm., 12 March 2021). She further subscribed that due to the lawless nature of the Nigerian society Nigerians are used to living lawless lives, hence, most Nigerians do not behave well as their normal way of life, and therefore, Nigerian migrants except few that are well trained do not behave well in the receiving country (Aisha pers. comm., 12 March 2021).

As noted in Genesis 47:7-10, Jacob proved that migrants are supposed to be humble and hospitable to their receiving countries. Jacob's bowing to the Pharaoh shows that migrants are not supposed to be proud, arrogant and disobedient in the destination country. Nigerian migrants have also made negative impacts on the development of their destination countries. Some Nigerian migrants engage in sex trafficking. Nigerian ladies from Edo state are mostly the culprits. In Benin City, the capital of Edo state, women who returned from Italy having worked as prostitutes are popularly referred to as Italos (Ref World 2003) Furthermore, Clem lamented that in Dubai, Nigerian migrants killed a Dubai Policeman in Deira who requested to know their migrant status (Clem, pers. comm., 13 October 2016). These Nigerian migrants were alleged to be members of Nigerian Eiye Confraternity Boys. These made the United Arab Emirates government place a visa ban on Nigerian migrants.

The narrative of Genesis 47:1-12, with emphasis on verse 12, gave a detailed analysis of how the people of Egypt took care of Jacob and his family. A careful appraisal reveals that migrants are to be provided with shelter, food and social protection.

There are also reports of witch-haunting of Nigerian migrants notwithstanding how benevolent and committed to the development of the destination country they tend to be. Remi Awogboro reported his experiences as a Nigerian in other countries. He said, 'If I am not working, people think I am on the dole or I am collecting money. If I am working, people think I have to come to take over their job' (Irish Times 2004).
This indicates that no matter what the average Nigerian migrant does to make ends meet, they are criticized. Some Nigerian migrants are hardworking people in their destination countries. The citizens of destination countries believe that Nigerian migrants always want to take hold of every opportunity.

In finding solution to the problem, there should be the provision of adequate enlightenment and information to promote regular migration amongst Nigerians. This could be done through posters, handbills and even short seminars at the premises of the Nigerian immigration service, Nigerian Airport Authorities and Nigerian Television Authority.

Nigerian migrants should endeavour to present themselves to the authorities of their destination countries. In the same vein, Nigerian residents in Europe should not participate in the illegality involved in bringing in irregular migrants. The time spent fine-tuning methods to circumvent migration laws of countries should be spent procuring the right papers and accessing the right routes.

Nigerian migrants should endeavour to have a cogent reason for seeking solace in developed countries. If it is schooling, football career or business deal, that should be adhered to with transparency and honesty. The issue of migrating to other developed countries with nothing in mind to do, with no relations to stay with and with a criminal motive contributes in no small way in worsening the Nigerian migrant crises. Clifford (pers. comm., 16 May 2020) emphasised that Nigerian migrants are to work hard, be patient and focused. Rome was not built in a day. If they imbibe these virtues, they will succeed. For the foreign governments, the world has become a global village. They cannot run away from it, hence the earlier they start integrating migrants and making them feel at home the better for them or they will have enemies in their bedrooms with time.

Eunice on her own part explains that, before leaving Nigeria, Nigerian migrants should always make sure that they know why they are travelling, what they will be doing in the country they are going to, and that they have a means of survival over there. According to Grace (pers. comm., 12 June 2020) 'if you are not travelling out to study, then you should be going there to do a legitimate business, or do a legitimate work or anything else that is genuine and within the confines of the law of the country in question. Otherwise, stay back in Nigeria to avoid falling victim of human trafficking'.

To the government of receiving countries, Eunice (pers. comm., 12 March 2021) said that, 'governments across the world should sensitise their citizens on the need to be welcoming and empathic towards foreigners. In this age and time, I do not think any country can thrive without international relations, particularly through opening their doors to foreigners who are skilled and willing to contribute to the economic growth of the country, even more than a large percentage of their citizens.' 
The government should also prioritize the security and safety of foreigners living in their country. Furthermore, the government of the receiving countries should give more support to those who legally migrate to their countries. On her part, Blessing (pers. comm., 06 May 2020) lucidly observed that:

\begin{abstract}
Nigerian migrants should be of good behaviour, obey the law of the land where they migrated to. They should endeavour to avoid anything that will make people point accusing fingers at them, thereby, representing Nigeria well. Government of the receiving county should not be hostile to Nigerians because of upholding a single story about Nigerians. They should not generalise things, thereby, counting all Nigerians as dubious because of the experience they had with some Nigerians. Everyone should be treated well, and respected.
\end{abstract}

The migrants led by Jacob were able to enjoy security and economic sustainability because of their moderation, skills and ability to embark on regular migration. In relation to the Nigerian migrants, regular migrants are evenly cared for, whilst the irregular ones are most times easily harassed. Migration has social, cultural, economic, and the political effects on the giving and receiving country. This is so because it involves the movement of people from one place to the other. These effects touch on the Nigerian migrants, Nigeria as a geographic location, and the receiving country.

\section{Conclusion}

Ethical perspectives in Genesis 47:1-12 entail the provision of sanctuary for Nigerian migrants by country of destination. The social ethics, just as in the pericope, encourage the provision of a safe place for Nigerian migrants in the face of threats. Many reasons can be adduced as responsible for the mass migration of Nigerians to other countries. They include poverty, underdevelopment, threats to life and the need to find a sustainable economic basis for their lives and those of their dependants. Moreover, on the basis of Genesis 47 , the onus lies with the government of receiving countries to take proper care of regular Nigerian migrants. Furthermore, Nigerians are called upon not to engage in any irregular migration for any reason. Most times, news filter the internet with regard to the maltreatment melted to irregular Nigerian migrants - most times have led to their deaths or extreme incapacitation. Taking a dangerous journey through Libya or through the Mediterranean in Tunisia has continued to spell doom for Nigerians. Genesis 47:1-12 encourages care and support for regular migrants and also dissuades people from engaging in irregular migration for economic gains.

\section{Acknowledgements Competing interests}

The authors declare that they have no financial or personal relationships that may have inappropriately influenced them in writing this article.

\section{Authors' contributions}

F.C.U., M.J.O. and S.N. contributed equally to the writing of this article.

\section{Ethical considerations}

This article followed all ethical standards for research without direct contact with human or animal subjects.

\section{Funding information}

This research received no specific grant from any funding agency in the public, commercial or not-for-profit sectors.

\section{Data availability}

Data sharing is not applicable to this article as no new data were created or analysed in this study.

\section{Disclaimer}

The views and opinions expressed in this article are those of the authors and do not necessarily reflect the official policy or position of any affiliated agency of the authors.

\section{References}

Abara, B., 2019, How young Nigerians are investing to leave the country, viewed 06 September 2019, from https://nairametrics.com/2019/09/06/how-much-itcosts-young-nigerians-to-leave-nigeria/.

Adigwe, H.A. \& Arubalueze, H.I., 2004, Christian religious knowledge for senior secondary schools, Yaoundé, PressBook Limited, p. 23.

Blue, 2021, Genesis chapter 47, viewed 25 February 2021, from https://www.biblestudys.org/Bible\%20Books/Genesis/Genesis\%20Chapter\%2047.html.

Clarke, A., 1832, Commentary on Genesis 47, in The Adam Clarke Commentary, viewed 20 May 2021, from https://www.studylight.org/commentaries/eng/acc/ genesis-47.html.

Clifford, R.J. \& Murphy, R.E., 2006, 'Genesis', in R.E. Brown (ed.), The New Jerome Biblical Commentary, pp. 40-44, Theological Publications in India, Bangalore.

Desmond, A. \& Baker, D.W. (ed.), 2003, Dictionary of the Old Testament, InterVarsity Press, Downers Grove, IL.

Dockery, W., 2018, 'Nigerians leave home due to war, poor economy', Oral Interview, Infomigrants, 27 August, 2018, p. 1.

Guzik, D., 2018, Genesis 45 - Joseph is reunited with his brothers, viewed 09 June 2021, from https://enduringword.com/bible-commentary/genesis-45/.

Henry, M., 2006, Matthew Henry commentary, Hendrickson Publishers Inc., Peabody, MA.

Irish Times, 2004, 'We are a hard-working people', The Irish Times, 08 May, 2004 viewed 12 December 2019, from https://www.irishtimes.com/news/we-are-aviewed 12 December 2019, from
hard-working-people-1.1139696.

Kept, P., 2014, God's wonderful plan (Gen 47:1-31), viewed 25 June 2014, from http:// www.thefellowship.site/archives/gods-wonderful-plan.

Lee, L.W., 2001, The character of God in the Book of Genesis, A narrative appraisal, Westminster John Knox Press, Louisville, KY.

Moss, R.W., 1930, 'Joseph', in J. Hastings \& J. SelBie (eds.), Dictionary of the Bible, Charles Scribners Sons, New York, NY.

Obiorah, J., 2019, 'Leviticus 19:33-34 and care for migrants: An African perspective', in C. Mbonu, C.U. Manus, P. Degini \& P. Poucouta (eds.), Migration in the Bible Abidjan, Pan African Association of Catholic Exegetes.

Olaide, O., 2020, 'Niger Republic deports 42 Nigerians for illegal entry', The Punch, July 17.

Ozuru, G. \& Okereke, P., 2019, "Towards a human rights approach for the treatment of migrants in Nigeria', Nnamdi Azikiwe University Journal of International Law and migrants in Nigeria', Nna
Jurisprudence 10(1), 94.

Philpot, J.M., 2018, 'Was Joseph a type of Daniel? Typological correspondence in Genesis 37-50 and Daniel 1-6', Journal of the Evangelical Theological Society 61(4), 694 .

Pulse, 2018, Italian embassy records 1,185 Nigerians with fake documents, viewed 17 February 2018, from https://www.pulse.ng/news/metro/everywhere-we-goitalian-embassy-records-1185-nigerians-with-fake-documents/9b54kg0.

Ref World, 2003, Nigeria: A prostitution ring known as Italo Mama, Immigration and Refugee Board of Canada, viewed 16 May 2021, from https://www.refworld.org/ docid/3f7d4de538.html. 
Scullion, J., 1991, Genesis 37-50: A commentary, University Press, Cambridge.

Study, 2020, Genesis Chapter 47, viewed 20 June 2021, from https://www.biblestudys.org/Bible20Books/Genesis/Genesis\%20Chapter\%2047.html.

Swaggart, J., 2013, The Expositors Bible Baton Rouge, Jimmy Swaggart Ministries, New Orleans, LA.
United Nations High Commissioner for Human Rights, Labour Migration Policy for Nigeria, Federal Ministry of Labour and Productivity, Revised December, 2020, Issues
in Nigerian migration, viewed 12 December 2020, from https://www.ohchr.org/ Documents/Issues/SRMigrants/submissions/Nigeria_NHRI_Annex3_Submission_GAReport.pdf.

Vawter, B., 1956, A path through Genesis, Sheed \& Ward, New York, NY. 